\title{
Multivariate characterization of morphological traits in Burkina Faso sheep
}

\author{
A. Traoré ${ }^{a, b}$, H.H. Tamboura ${ }^{a}$, A. Kaboré ${ }^{a}$, L.J. Royo $^{b}$, I. Fernández $^{b}$, I. Álvarez ${ }^{b}$, M. Sangaréc $^{\text {, }}$ \\ D. Bouchel ${ }^{d}$, J.P. Poivey ${ }^{\mathrm{e}}$, D. Francois ${ }^{\mathrm{f}, 1}$, A. Toguyeni $^{\mathrm{c}}$, L. Sawadogo ${ }^{\mathrm{g}}$, F. Goyache ${ }^{\mathrm{b}, *}$ \\ a INERA, 04 BP 8645 Ouagadougou 04, Burkina Faso, Spain \\ b SERIDA-Somió, C/Camino de los Claveles 604, E-33203 Gijón (Asturias), Spain \\ c CIRDES, 01 BP 454 Bobo-Dioulasso, Burkina Faso, Spain \\ d ISRA, BP 24187 Dakar Ouakam, Sénégal; Spain \\ e CIRAD-Campus de Baillarguet - F 34000 Montpellier, France \\ f INRA-SAGA Toulouse, BP 25627, F-31326 Castanet Tolosan Cedex, France \\ g Université de Ouagadougou. (UFR/SVT) 03 BP 7021 Ouagadougou 03, Burkina Faso, Spain
}

\section{A R T I C L E I N F O}

\section{Article history:}

Received 1 April 2008

Received in revised form

18 September 2008

Accepted 19 September 2008

\section{Keywords:}

Morphological variability

Djallonké sheep

Mossi sheep

Burkina-Sahel sheep

West Africa

Genetic resources

\begin{abstract}
A B S T R A C T
A total of 6440 female sheep from Burkina Faso were scored for seven body measurements and four qualitative morphological traits. Sampling included the three main environmental areas and sheep breeds of Burkina Faso: the Sahel area (Burkina-Sahel sheep), the SudanSahel area (Mossi sheep) and the Sudan area (Djallonké sheep). Canonical analyses showed that differences in body measurements between the Sudan and the Sudan-Sahel sheep were small even though most body traits showed higher average values in the Burkina-Sahel sheep: the shortest Mahalanobis distance was found between the Sudan and the SudanSahel populations (1.54), whilst that between the Sudan and the Sahelian populations was the largest (7.88). Discriminant analysis showed that most Sudan (Djallonké) individuals (60.85\%) were classified as Sudan-Sahel (Mossi) individuals whilst most Burkina-Sahel individuals were classified into their environmental area of sampling (89.46\%). Correspondence analyses indicated that the Burkina-Sahel sheep population clustered together with dropping ears, black and brown colour patterns and presence of wattles, the Sudan sheep were closely associated with long hair and vertical and curled ears and that the Sudan-Sahel sheep did not have clear associations with qualitative phenotypic traits. At the morphological level, the Sudan-Sahel (Mossi) sheep population can be considered a geographical subpopulation belonging to the Djallonké breed, showing some particularities, namely larger body size, due to the particular environmental condition of the area in which it is managed and a continuous gene flow from Sahelian sheep, The information reported in this study will be the basis for the establishment of further characterization, conservation and selection strategies for Burkina Faso sheep.
\end{abstract}

(c) 2008 Elsevier B.V. All rights reserved.

\footnotetext{
* Corresponding author. Tel.: +34 985195303; fax: +34 985195310.

E-mail address: foyache@serida.org (F. Goyache).

1 Tel.: +33 561285190 .
}

\section{Introduction}

The Burkina Faso sheep population numbers 6,702,640 heads with an annual growth rate of 3\% (ENEC II, 2004). In Burkina Faso, sheep management is carried out under very harsh and traditional conditions with a large variation in flock sizes. Sheep are widely distributed all over 
the country providing a wide range of products of major economical importance for the maintenance of rural populations and alleviation of poverty. Sheep also have a major cultural importance due to their traditional use in rites and celebrations (Tamboura and Berté, 1994).

In spite of its national importance, information on sheep resources of Burkina Faso is scarce (Traoré et al., 2006) and mainly focused on the assessment of reproduction and production performance (Tamboura et al., 1998). Most studies on characterization of native Burkina Faso livestock breeds have been done on goat and concentrated on gathering qualitative and body measurement traits (Sanfo et al., 2000; Traoré et al., 2006, submitted for publication). There is a need for the identification of sheep types at the national level to be further characterised at both the production and the genetic levels.

Even though no clearly defined breeds exist, it is widely accepted in Burkina Faso that native sheep can be divided into three major types according to geographic location and morphological traits: (i) Burkina-Sahel sheep, (ii) Mossi sheep and (iii) Djallonké sheep. However, information from the native Burkina Faso sheep breeds is scarce and major databases developed to monitor the large variety of domestic animal genetic resources worldwide, such as DAGRIS (http://dagris.ilri.cgiar.org; DAGRIS, 2007) or DAD-IS (FAO; http://dad.fao.org/), only include limited information. Since the breed is the operational unit for the assessment of livestock diversity all over the world (Duchev and Groeneveld, 2006; Duchev et al., 2006; Simon, 1999), contributions to characterization of local domestic animal populations are of major importance in developing countries.

The first step of the characterization of local genetic resources is based on the knowledge of variation in the morphological traits (Delgado et al., 2001). Multifactorial analyses of morphological traits have been proved to be suitable in assessing the variation within a population and can discriminate different population types when all measured morphological variables are considered simultaneously. These kinds of studies are commonly reported in goats (Capote et al., 1998; Dossa et al., 2007; Herrera et al., 1996; Jordana et al., 1993; Zaitoun et al., 2005). However, multivariate analyses on morphological traits are rarely reported in sheep (Riva et al., 2004).

In this work, we analyzed seven body measurements and four qualitative phenotypic traits in Burkina Faso sheep. Data were obtained from an extensive sampling all over the Burkina Faso territory to better characterize the morphological variation in the whole Burkina Faso sheep population. This general aim was to explore the possibility of distinguishing different breeds among the Burkina Faso sheep populations.

\section{Materials and methods}

\subsection{Environmental areas and sheep populations}

The Burkina Faso territory can be divided into three main environmental areas according to climate conditions and types of vegetation (Ouadba, 1997; see Fig. 1): (a) the Sahel area; (b) the Sudan-Sahel area; and (c) the Sudan area. The Sahel domain is an arid area covering the northern part of Burkina Faso (from latitude $13^{\circ} 5^{\prime} \mathrm{N}$ to $15^{\circ} 3^{\prime} \mathrm{N}$, approximately) with an annual rainfall $<600 \mathrm{~mm}$, high temperatures varying from $15^{\circ} \mathrm{C}$

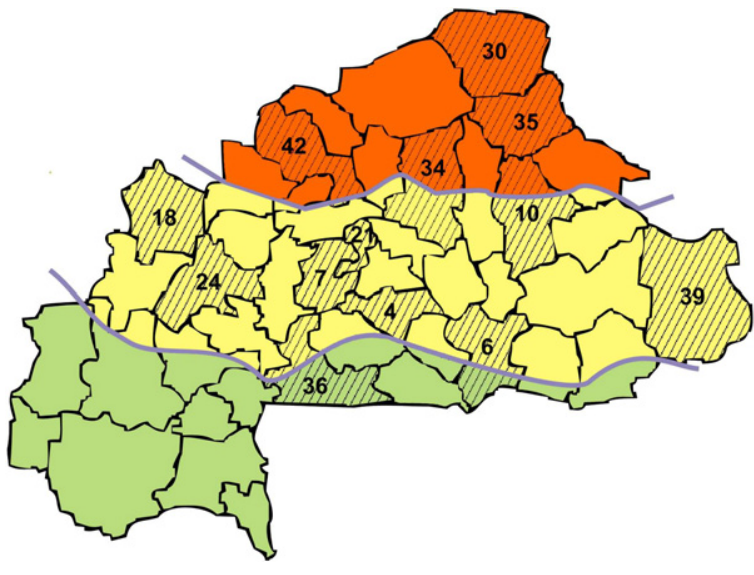

Fig. 1. Map, adapted from Ouadba (1997), illustrating the division in provinces of Burkina Faso and the limits of the main environmental area of identified in the country. The dashed provinces are those in which the sampling was carried out. Numbers are consistent with those given in Table 1.

to $47^{\circ} \mathrm{C}$, and grassy, bushy, shrubby and thicket steppe vegetation, usually quite sparse, with ligneous species that may form penetrable bushes. The Sudan-Sahel domain is a transitional zone with regards to rainfall and temperature, covering the central part of the country (roughly from latitude $11^{\circ} 3^{\prime} \mathrm{N}$ to $13^{\circ} 5^{\prime} \mathrm{N}$ ), with a short rainy season from June to September and very variable rainfall with average of $750 \mathrm{~mm}$ per year; temperature ranging from $20^{\circ} \mathrm{C}$ to $42^{\circ} \mathrm{C}$, and vegetation varying from North to South with better hydric conditions, from the Sahel to the Sudan savannah and clear forests in the Southwestern extreme of the domain. The Sudan domain covers the area of Southern Burkina Faso (latitude from $9^{\circ} 3^{\prime} \mathrm{N}$ to $11^{\circ} 3^{\prime} \mathrm{N}$ ) that shares with the Sudan-Sahel area a similar rainy season with annual rainfall $>900 \mathrm{~mm}$ and a predominance of woodlands and Sudan- and Guinean-type savannahs; temperatures are relatively low varying from $17^{\circ} \mathrm{C}$ to $35^{\circ} \mathrm{C}$.

The three environmental areas described above are assumed to be the habitat of three different sheep breeds: (a) the Djallonké dwarf breed, located in the Sudan area, is a hairy-thin tailed sheep belonging to the West African Dwarf sheep family, which is spread in a wide area of West Africa, from southern Senegal to Chad, and to the south in Cameroon, Gabon and Congo; (b) the Burkina-Sahel breed, which inhabits semi-arid and arid areas of Northern Burkina Faso and Western-Central Mali and maintained by the Peul (Fulani) agro-pastoral communities; and (c) the Mossi breed, located in the Sudan-Sahel area of Burkina Faso, which is considered a transition breed probably nearer to the Djallonké breed (Tambourá et al., 1998; Traoré et al., 2006). Sheep populations sampled in each environmental area (Sahel, Sudan-Sahel and Sudan areas) will be considered as belonging to a different breed (Burkina-Sahel, Mossi and Djallonké breeds, respectively).

The sheep populations of the three environmental areas of Burkina Faso (Sahel, Sudan-Sahel and Sudan) number, respectively, 2.1, 3.0 and 1.6 million heads (ENEC II, 2004).

\subsection{Data collection}

From May 2006 to April 2007, sampling of sheep populations was carried out from a total of 105 villages (VIL) belonging to 13 provinces of Burkina Faso, covering the three identified environmental areas (Table 1; Fig. 1). Within VIL, from two to five different flocks were sampled. Following the methodology of Bouchel (1995), a total of 6440 female individuals from 2.5 to 5 years of age were scored for seven body measurements and four qualitative traits. The age of the animal was estimated from its dentition. Up to 2937 individuals were sampled in the Sahel area, 2602 in the Sudan-Sahel area and 901 in the Sudan area (Table 1). Note that although the Sudan samples only accounts for $14 \%$ of the total, this is roughly consistent with the distribution of sheep among Burkina Faso areas. The Sudan area only accounts for $23 \%$ of total sheep (ENEC II, 2004).

Body measurements were carried out by four different technicians using Lydthin stick, tape measure and Vernier caliper; animals were put 
Table 1

Distribution of sampling.

\begin{tabular}{|c|c|c|c|c|c|}
\hline \multirow[b]{2}{*}{ Provinces $^{\mathrm{a}}$} & \multicolumn{2}{|c|}{ Number of samples } & \multicolumn{3}{|c|}{ Distribution per areas } \\
\hline & Villages & Individuals & Sahel & Sudan-Sahel & Sudan \\
\hline 4. Bazéga & 4 & 245 & & 245 & \\
\hline 6. Boulgou & 6 & 340 & & & 340 \\
\hline 7. Boulkiemdé & 9 & 532 & & 532 & \\
\hline 10. Gnagna & 10 & 601 & 420 & 181 & \\
\hline 18. Kossi & 4 & 240 & & 240 & \\
\hline 21. Kourweogo & 1 & 121 & & 121 & \\
\hline 24. Mouhoun & 7 & 427 & & 427 & \\
\hline 30. Oudalan & 8 & 490 & 490 & & \\
\hline 34. Sanmatenga & 13 & 785 & 484 & 301 & \\
\hline 35. Seno & 14 & 871 & 871 & & \\
\hline 36. Sissili & 9 & 561 & & & 561 \\
\hline 39. Тароа & 9 & 555 & & 555 & \\
\hline 42. Yatenga & 11 & 672 & 672 & & \\
\hline Totals & 105 & 6440 & 2937 & 2602 & 901 \\
\hline
\end{tabular}

a The official administrative number of each province is given before their name. Numbers are consistent with those shown in Fig. 1.

on a flat floor and held by the respective owners. The seven body measurements obtained were (Fig. 2): Head Length (HL), Nose Perimeter (NP), Tail Length (TL), Ear Length (EL), Thorax Depth (TD), Body Length (BL), and Height at Withers (HW). The four qualitative traits scored were (see Table 3): colour pattern (CP; with five levels: white, black, spotted in black, brown and spotted in brown), presence of Wattles (W; with two levels: presence and absence), incidence of long hairs (LH; with two levels: presence and absence) and ear position (EP; with four levels: vertical, horizontal, curled and dropped).

\subsection{Statistical analyses}

Statistical analyses were carried out using the SAS/STAT package (1999). Basic statistics for the body measurements and qualitative traits were obtained using the PROC UNIVARIATE and PROC FREQ, respectively. The influence of the environmental area on the seven body traits measured was assessed using the PROC MIXED, fitting a model including as effects the Area (with three levels: Sahel, Sudan-Sahel and Sudan) and VIL. VIL was defined as a random effect, nested within area to account for the non-independency of sampling in each VIL. Least square means and their corresponding standard errors were obtained for each body trait by area level. Additionally, Duncan's multiple-range test was performed on all area means of body measurement traits using PROC GLM. The CANDISC procedure was used to perform canonical analyses to derive canonical functions, linear combinations of the quantitative variables that summarize variation

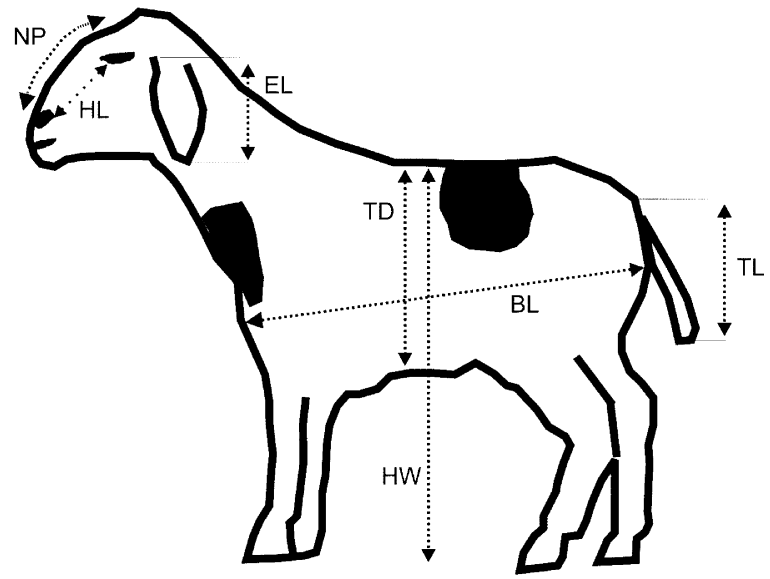

Fig. 2. Zoometrical variables studied and their reference points. NP: Nose Perimeter; HL: Head Length, TL: Tail Length, EL: Ear Length; TD: Thorax Depth; BL: Body Length; HW: Height at Withers. between Areas and compute the between-Areas Mahalanobis distance matrix. The ability of the computed canonical functions to assign each individual sheep to its sampling area was calculated as the percent of correct assignment using the DISCRIM procedure. The association between the qualitative traits was assessed via a correspondence analysis using the PROC CORRESP of SAS. When necessary for descriptive purposes, canonical variables and correspondence analysis dimensions were plotted using Microsoft Excel ${ }^{\mathrm{TM}}$.

\section{Results}

\subsection{Continuous traits}

Least-squared means for the body measurement traits by environmental areas are given in Table 2. Overall, the Burkina-Sahel sheep had the highest values for all the analyzed traits $(17.99 \mathrm{~cm}$ for NP, $16.52 \mathrm{~cm}$ for $\mathrm{HL}, 37.07 \mathrm{~cm}$ for $\mathrm{TL}, 16.80 \mathrm{~cm}$ for EL, 69.09 for $\mathrm{HW}, 29.74 \mathrm{~cm}$ for TD and $60.81 \mathrm{~cm}$ for BL). Differences between the Sudan (Djallonké) and the Sudan-Sahel (Mossi) sheep were statistically significant $(p<0.001)$ even though biologically negligible for HL, TD and BL. The other analyzed traits showed higher average values in the Sudan-Sahel sheep.

\subsection{Qualitative traits}

The percentage of each level of the four qualitative traits recorded for the total population and for each environmental area is given in Table 3. The Burkina Faso native sheep was mainly spotted in black (45.96\%) or brown (36.74\%), short-haired (93.34\%), frequent absence of wattles (87.70) and with dropping ears (58.31\%). Most sheep with dropping ears were found in Sahel area (40.93\% of the whole sample) whilst most animals with horizontal ears were found in Sudan-Sahel area (21.63\%).

\subsection{Multivariate analyses}

The canonical analysis identified two statistically significant $(p<0.001)$ canonical variables (CAN1 and CAN2). The CAN1 and CAN2 accounted for $90.9 \%$ and $9.1 \%$ of the total variation, respectively. Fig. 2 shows a bi-dimensional plot illustrating the relationships between body measurements: on the $X$-axis, NP is separated from the clearly linear body measurements (HL, HW, TL, EL and TD) whilst the $Y$-axis allows to differentiate $\mathrm{HL}$ and EL from the main group of body measurements (HW, TL and TD). The between-environmental areas Mahalanobis distance matrix is given in Table 4 . All pairwise distances were significant $(p<0.0001)$. The hypothesis that the areas' means are equal in the populations analyzed was also tested using Wilks' Lambda. This parameter took a significant value $(p<0.0001)$ of $0.36290244(F=605.68$; degrees of freedom $=14$ ) thus showing that differences found between areas were statistically different from zero. The largest distance was found between the Sahel and Sudan areas (7.88) whilst the sheep populations from the Sudan and the Sudan-Sahel areas were poorly differentiated (1.54). The values computed for CAN1 and CAN2 for each individual were plotted by environmental areas (Fig. 3). The Sudan (Djallonké) individuals were the most homogeneous and clustered together on the left hand of the $X$-axis; the Sahe- 
Table 2

Raw means with their standard error (s.e.) and coefficient of variation (CV) for each of the seven body measurements and two indices analyzed. Least-squared means and their standard errors (LSmean \pm s.e.) are also given by environmental areas.

\begin{tabular}{|c|c|c|c|c|c|}
\hline \multirow[t]{2}{*}{ Trait } & \multirow{2}{*}{$\begin{array}{l}\text { Overall } \\
\text { Raw mean } \pm \text { s.e. }\end{array}$} & \multicolumn{4}{|c|}{ Environmental areas } \\
\hline & & $\mathrm{CV}$ & $\begin{array}{l}\text { Sahel } \\
\text { LSmean } \pm \text { s.e. }\end{array}$ & $\begin{array}{l}\text { Sudan } \\
\text { LSmean } \pm \text { s.e. }\end{array}$ & $\begin{array}{l}\text { Sudan-Sahel } \\
\text { LSmean } \pm \text { s.e. }\end{array}$ \\
\hline Nose Perimeter & $16.19 \pm 0.04$ & 21.43 & $17.99^{a} \pm 0.03$ & $12.39^{b} \pm 0.05$ & $15.59^{c} \pm 0.03$ \\
\hline Head Length & $14.47 \pm 0.04$ & 21.39 & $16.52^{\mathrm{a}} \pm 0.02$ & $12.38^{\mathrm{b}} \pm 0.74$ & $12.43^{c} \pm 0.02$ \\
\hline Tail Length & $31.83 \pm 0.11$ & 27.77 & $37.07^{a} \pm 0.11$ & $24.50^{\mathrm{b}} \pm 0.21$ & $28.46^{c} \pm 0.12$ \\
\hline Ear Length & $13.78 \pm 0.05$ & 29.70 & $16.80^{\mathrm{a}} \pm 0.03$ & $9.43^{\mathrm{b}} \pm 0.07$ & $11.81^{c} \pm 0.04$ \\
\hline Height at Withers & $63.49 \pm 0.12$ & 15.01 & $69.09^{a} \pm 0.12$ & $56.49^{b} \pm 0.22$ & $59.58^{c} \pm 0.13$ \\
\hline Thorax Depth & $27.81 \pm 0.04$ & 12.47 & $29.74^{\mathrm{a}} \pm 0.04$ & $26.07^{b} \pm 0.08$ & $26.20^{c} \pm 0.04$ \\
\hline Body Length & $57.33 \pm 0.13$ & 18.81 & $60.81^{a} \pm 0.16$ & $54.10^{\mathrm{b}} \pm 0.29$ & $54.45^{c} \pm 0.17$ \\
\hline
\end{tabular}

Different letters as superscripts mean significant differences $(p<0.05)$.

Table 3

Frequency of each class level of the qualitative traits scored in Burkina Faso sheep (and percentage for each qualitative trait in brackets) per environmental area. Overall frequencies are also given.

\begin{tabular}{|c|c|c|c|c|c|}
\hline \multirow[t]{2}{*}{ Traits } & \multirow[t]{2}{*}{ Class level } & \multicolumn{4}{|c|}{ Environmental area } \\
\hline & & Sahel & Sudan & Sudan-Sahel & Overall \\
\hline Coat pattern & $\begin{array}{l}\text { White } \\
\text { Black } \\
\text { Spotted in black } \\
\text { Brown } \\
\text { Spotted in brown }\end{array}$ & $\begin{array}{c}283(9.64) \\
64(2.18) \\
1336(45.49) \\
63(2.15) \\
1191(40.55)\end{array}$ & $\begin{array}{c}197(21.86) \\
8(0.89) \\
486(53.94) \\
1(0.11) \\
209(23.2)\end{array}$ & $\begin{array}{c}446(17.14) \\
31(1.19) \\
1138(43.74) \\
21(0.81) \\
966(37.13)\end{array}$ & $\begin{array}{c}926(14.38) \\
103(1.60) \\
2960(45.96) \\
85(1.32) \\
2366(36.74)\end{array}$ \\
\hline Wattles & $\begin{array}{l}\text { Absence } \\
\text { Presence }\end{array}$ & $\begin{array}{r}2420(82.4) \\
517(17.60)\end{array}$ & $\begin{array}{c}847(94.01) \\
54(5.99)\end{array}$ & $\begin{array}{c}2381(91.51) \\
221(8.49)\end{array}$ & $\begin{array}{r}5648(87.7) \\
792(12.3)\end{array}$ \\
\hline Long hair & $\begin{array}{l}\text { Absence } \\
\text { Presence }\end{array}$ & $\begin{array}{c}2914(99.22) \\
23(0.78)\end{array}$ & $\begin{array}{l}695(77.14) \\
206(22.86)\end{array}$ & $\begin{array}{c}2402(92.31) \\
200(7.69)\end{array}$ & $\begin{array}{c}6011(93.34) \\
429(6.66)\end{array}$ \\
\hline Ear position & $\begin{array}{l}\text { Vertical } \\
\text { Horizontal } \\
\text { Curled } \\
\text { Dropping }\end{array}$ & $\begin{array}{c}0(0.00) \\
222(7.56) \\
79(2.69) \\
2636(89.75)\end{array}$ & $\begin{array}{c}9(1.00) \\
293(32.52) \\
511(56.71) \\
88(9.77)\end{array}$ & $\begin{array}{c}0(0.00) \\
1393(53.54) \\
178(6.84) \\
1031(39.62)\end{array}$ & $\begin{array}{c}9(0.14) \\
1908(29.63) \\
768(11.93) \\
3755(58.31)\end{array}$ \\
\hline
\end{tabular}

Chi-squared test showed that incidence of all the analyzed traits varied significantly among environmental areas $(p<0.001)$.

lians are mainly distributed on the positive values of the $X$-axis; and the Sudan-Sahel (Mossi) individuals showed an intermediate distribution but clearly biased toward the Sudan individuals. In this respect, the discriminant analysis carried out gave complementary information (Table 5). Most Sahel and Sudan-Sahel individuals were classified into their source population (89.46\% and $77.86 \%$ ) whilst most Sudan individuals (60.85\%) were classified as SudanSahel individuals. Roughly speaking, no Sahel individuals were classified as Sudanians and vice versa. However, a sig-

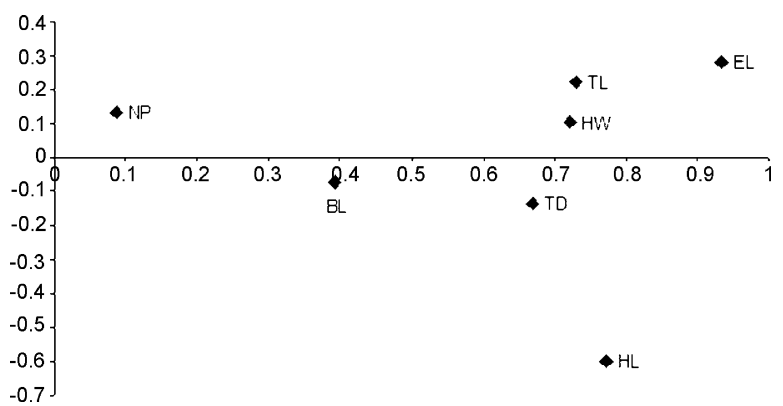

Fig. 3. Bi-dimensional plot illustrating the association between body measurements in Burkina Faso sheep assessed via canonical analysis. NP: Nose Perimeter; HL: Head Length, TL: Tail Length, EL: Ear Length; TD: Thorax Depth; BL: Body Length; HW: Height at Withers. nificant part of the Sahelian and Sudan-Sahel individuals ( $17.10 \%$ and $9.92 \%$, respectively) were 'erroneously' crossclassified.

A correspondence analysis was carried out on the four qualitative traits recorded. Fig. 4 shows the associations among the categories of the analyzed variables. The first and second identified dimensions explained, respectively, $39.6 \%$ and $29.1 \%$ of the total variation. On the identified dimensions, the Sahel area clustered together with drop-

\section{Table 4}

Mahalanobis distances between the sheep populations sampled in each environmental area identified in Burkina Faso.

\begin{tabular}{llc}
\hline Area & Sahel & Sudan \\
\hline Sudan-Sahel & 5.24 & 1.54 \\
Sudan & 7.88 & \\
\hline
\end{tabular}

\section{Table 5}

Percentage of classification into each environmental area for the Burkina Faso sheep individuals sampled, according to the environmental area of sampling, using morphostructural variables and discriminant analysis.

\begin{tabular}{lrcr}
\hline Area & Sahel & Sudan-Sahel & Sudan \\
\hline Sahel & 89.46 & 9.92 & 0.61 \\
Sudan-Sahel & 17.10 & 77.86 & 5.03 \\
Sudan & 0.33 & 60.85 & 38.82 \\
Total & 47.74 & 44.52 & 7.74 \\
\hline
\end{tabular}



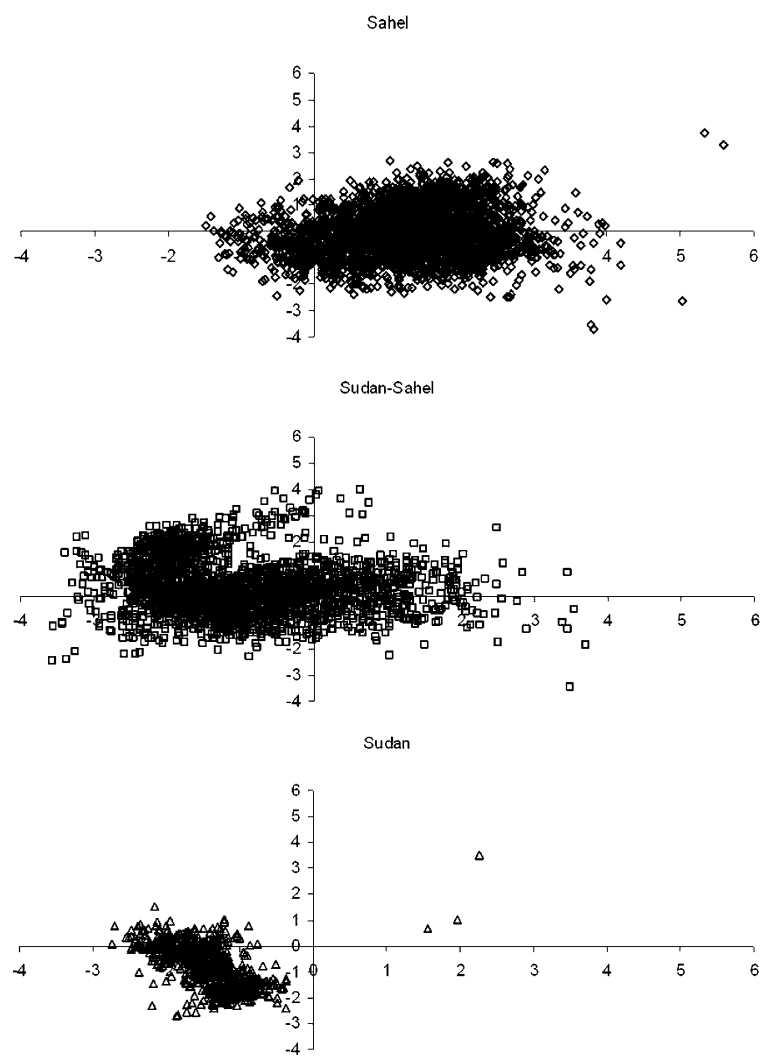

Fig. 4. Bi-dimensional representation of the canonical variables associated to the individuals sampled in each of the environmental areas of Burkina Faso.

ping ears, black and brown colour pattern and presence of wattles; the Sudan area was closely associated with long hair and vertical and curled ears; and the Sudan-Sahel area tended to cluster with horizontal ears but did not show clear associations with other qualitative traits.

\section{Discussion}

There is an increasing interest in the characterization of African small ruminant populations because of their major role in the maintenance of genetic resources as the basis of future improvement at both the production and the genetic levels (Dossa et al., 2007; Nsoso et al., 2004; Ouédraogo-Koné et al., 2006). Studies devoted to the morphological characterization of West African sheep are scarce and the average values obtained in this study for body measurements cannot be easily compared with others in the literature. Ngere (1973) reported an average HW of $48 \mathrm{~cm}$, ranging from 45 to $50 \mathrm{~cm}$, in Ghana West African Dwarf sheep. The very recent paper by Sowande and Sobola (2008) reported, in female Nigerian West African Dwarf sheep, average values for HW, BL, and HL of, respectively, $52.73,47.02$, and $18.24 \mathrm{~cm}$. The corresponding values assessed in this study for the Sudan (Djallonké) sheep of Burkina Faso (see Table 2) show large differences with those reported above, this could be explained by between-studies methodological differences but also by real differences between local populations belonging to the West African Dwarf sheep that have a wide geographical distribution. Results from the correspondence analyses also support the classification of the Sudan (Djallonké) sheep of Burkina Faso into the West African Dwarf sheep population which is phenotypically characterized by its small size but also because of the high frequency of longhaired individuals.

It is particularly difficult to find references on morphological studies involving sheep in the Sahel area. Wilson (1980) described the Malian Bambara sheep, spread in Central Mali near to the Sahelian area of Burkina Faso, as individuals with average $\mathrm{HW}$ of $74.10 \mathrm{~cm}$ in mature females, with toggles in a $25 \%$ of the individuals, semi-pendulous ears with EL varying from 11 to $14 \mathrm{~cm}$, long tail and predominantly white-coated. Overall, this description is consistent with the results obtained in this study for the Burkina-Sahel sheep (mean HW of $69.09 \mathrm{~cm}$, dropping ears and presence of wattles) and, in fact, Wilson (1980) considered the Bambara sheep of Mali as a part of the West African Fellata sheep which was, in turn, classified as Sahel sheep.

The low differentiation assessed between the Sudan (Djallonké) and Sudan-Sahel (Mossi) sheep using the Mahalanobis distance and the large classification errors obtained using the discriminant analysis (see Tables 4 and 5) do not give statistical support to separate these geographical sheep populations into two different breeds. In any case, the Sudan-Sahel sheep of Burkina Faso shows a large variability at the body size level thus supporting the hypothesis considering the Sudan-Sahel (Mossi) sheep as a transition population between the Sudan (Djallonké) and Sahel sheep populations. The Sudan-Sahel (Mossi) sheep can be considered as the northerner representative of the West African Dwarf sheep in Burkina Faso, occupying a particularly arid ecosystem and with an ancient and sustained introgression of the Sahelian sheep coming from North. These particular conditions would distinguish this sheep type from other West African Dwarf sheep populations. Moreover, no clear associations between the Sudan-Sahel sheep and morphological qualitative traits could be assessed using a correspondence analysis (see Fig. 5) also supporting the existence of large variability at this level within the Sudan-Sahel sheep of Burkina Faso probably due to a significant degree of admixture in this population.

Moreover, a significant proportion of cross-classification errors between the Burkina-Sahel and Sudan-Sahel (Mossi) sheep (17.10\% and $9.92 \%$, respectively; see Table 5 ) was assessed using discriminant analyses thus confirming the introgression of the Sahelian sheep southwards. There are three main reasons explaining this introgression: (a) the action of the Peuls (Dossa et al., 2007), nomadic stockbreeders inhabiting the Sahelian area of Burkina Faso and other countries of West Africa, that also are active operators in the sheep market all over the countryside; (b) the increase of the duration of the dry seasons in the region since the 1980s, favouring the migration of the Sahelian sheep into the Sudan-Sahel and Sudan areas; and (c) the general interest of the Burkina Faso breeders in obtaining products with bigger conformation. Moreover, the introgression of the Sahelian sheep into the Sudan areas can be limited and mediated by the Sudan-Sahel population due 


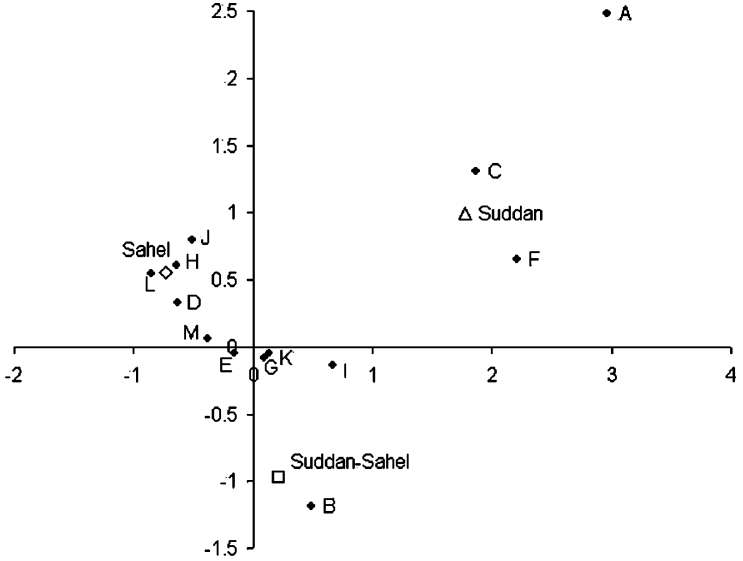

Fig. 5. Among qualitative variables relationship assessed via correspondence analysis. (A) Vertical ears; (B) horizontal ears; (C) curled ears; (D) dropping ears; (E) short hair; (F) long hair; (G) absence of wattles; (H) presence of wattles; (I) white coated; (J) black coated; (K) spotted in black; (L) brown coated; (M) spotted in brown. (For interpretation of the references to color in this figure legend, the reader is referred to the web version of the article.)

to the fact that the Sahelian sheep is not trypanotolerant thus limiting its possibilities of use for reproduction in the southernmost Burkina Faso flocks.

\section{Conclusions}

A significant morphological variation was found in Burkina Faso sheep mainly due to the existence of two main populations (Djallonké and Burkina-Sahel) with probable different genetic origins. The Mossi sheep breed can be considered a geographical subpopulation belonging to the Djallonké breed, showing some particularities, namely larger body size, due to the particular environmental condition of the area in which it is managed (Sudan-Sahel) and a continuous gene flow from Sahelian sheep, probably more intense with the desertification process of Western Africa. This information will be the basis of further characterization, conservation and selection strategies in Burkina Faso sheep.

\section{Acknowledgments}

This paper was partially funded by grants from Fonds de Solidarité Prioritaire (FSP-INERA-CIRDES), the International Atomic Energy Agency, No. BKF/5/006 and MEC-INIA, No. RZ2004-00007-C02. The research stay of Amadou Traoré, DVM, in SERIDA-Somió was supported by a grant fellowship from the International Atomic Energy Agency, No. BKF/06023. The authors are indebted to the Directors of Animal Resources Offices of the sampled provinces (Burkina Faso) for introducing them to breeders. In memoriam to Georges-Alfred Ky.

\section{References}

Bouchel, D., 1995. Contribution à l'étude des indices morpho-biométriques et de leur condition d'emploi pour la cartographie des ressources génétiques caprines. Mémoire de DIRS, Université François Rabelais de Tours, $40 \mathrm{pp}$.

Capote, J., Delgado, J.V., Fresno, M., Camacho, M.E., Molina, A., 1998. Morphological variability in the Canary goat population. Small Rumin. Res. 27, 162-167.

DAGRIS, 2007. In: Rege, J.E.O., Hanotte, O., Mamo, Y., Asrat, B., Dessie, T. (Eds.), Domestic Animal Genetic Resources Information System (DAGRIS). International Livestock Research Institute, Addis Ababa, Ethiopia, http://dagris.ilri.cgiar.org.

Dossa, L.H., Wollny, C., Gauly, M., 2007. Spatial variation in goat populations from Benin as revealed by multivariate analysis of morphological traits. Small Rumin. Res. 73, 150-159.

Delgado, J.V., Barba, C., Camacho, M.E., Sereno, F.T.P.S., Martínez, A., VegaPla, J.L., 2001. Caracterización de los animales domésticos en España. AGRI 29, 7-18.

Duchev, Z., Groeneveld, E., 2006. Improving the monitoring of animal genetic resources on National and International level. Arch. Anim. Breed. 49, 532-544.

Duchev, Z., Distl, O., Groeneveld, E., 2006. Early warning system for loss of diversity in European livestock breeds. Arch. Anim. Breed. 49, 521531.

ENEC II, 2004. Deuxième enquète nationale sur les effectifs du cheptel. Tome 2, 85 pp.

Herrera, M., Rodero, E., Gutierrez, M.J., Pena, F., Rodero, J.M., 1996. Application of multifactorial discriminant analysis in the morphostructural differentiation of Andalusian caprine breeds. Small Rumin. Res. 22, 39-47.

Jordana, J., Ribo, O., Pelegrin, M., 1993. Analysis of genetic relationships from morphological characters in Spanish goat breeds. Small Rumin. Res. 12, 301-314.

Ngere, L.O., 1973. Size and growth rate of the West African dwarf sheep and a new breed, the Nungua Blackhead of Ghana'. Ghana J. Agric. Sci. 6, 113-117.

Nsoso, S.J., Podisi, B., Otsogile, E., Mokhutshwane, B.S., Ahmadu, B., 2004. Phenotypic characterization of indigenous Tswana goats and sheep in Botswana: categorical traits. Trop. Anim. Health. Prod. 36, 789-800.

Ouadba, J.M., 1997. Elaboration d'une monographie nationale sur la diversité biologique: Collecte de données biologique, considération écologiques. Minist. Envir. et de l'Eau, Ouagadougou, p. 45.

Ouédraogo-Koné, S., Kaboré-Zoungrana, C.Y., Ledin, I., 2006. Behaviour of goats, sheep and cattle on natural pasture in the sub-humid zone of West Africa. Livest. Sci. 105, 244-252.

Riva, J., Rizzi, R., Marelli, S., Cavalchini, L.G., 2004. Body measurements in Bergamasca sheep. Small Rumin. Res. 55, 221-227.

Sanfo, R., Nianogo, A.J., Tamboura, H.H., 2000. Profil morpho-biométrique, évolution pondérale et indices de productivité de la chèvre du Sahel au Burkina Faso. Sci. Technol. 24, 68-76.

SAS/STAT, 1999. User's Guide, Release 8.2. SAS Institute Inc., 1999, Cary, NC, USA.

Simon, D.L., 1999. European approaches to conservation of farm animal genetic resources. AGRI 25, 79-99.

Sowande, O.S., Sobola, O.S., 2008. Body measurements of West African Dwarf sheep as parameters for estimation of live weight. Trop. Anim. Health Prod. 40, 433-439.

Tamboura, H., Sawadogo, L., Wereme, A., 1998. Caractéristiques temporelles et endocriniennes de la puberté et du cycle oestral chez la chèvre locale Mossi du Burkina Faso. Biotechnol. Agron. Soc. Environ. 2, 85-91.

Tamboura, H.; Berté, D., 1994. Systèmes traditionnelles d'élevage caprin sur le plateau central du Burkina Faso. Small ruminant research and development in Africa. Proceeding of the biennal conference of the African small ruminant research network. UICC, Kampala, Uganda, pp. 93-97.

Traoré, A., Tamboura, H.H., Kaboré, A., Royo, L.J., Fernández, I., Álvarez, I., Sangaré, M., Bouchel, D., Poivey, J.P., Francois, D, Toguyeni, A., Sawadogo, L., Goyache, F. Multivariate analyses on morphological traits in Burkina Faso goat. Arch. Anim. Breed., submitted for publication.

Traoré, A., Tamboura, H.H., Kaboré, A., Yaméogo, N., Bayala, B., Zaré, I., 2006. Caractérisation morphologique des petits ruminants de race locale Mossi au Burkina Faso. AGRI 39, 39-50.

Wilson, R.T., 1980. Population and production parameters of sheep under traditional management in semi-arid areas of Africa. Trop. Anim. Health Prod. 12, 243-250.

Zaitoun, I.S., Tabbaa, M.J., Bdour, S., 2005. Differentiation of native goat breeds of Jordan on the basis of morphostructural characteristics. Small Rumin. Res. 56, 173-182. 